\title{
Perbandingan Efisiensi Konversi Energi Panel Surya Tipe Polycrystaline dan Panel Surya Tipe Monocrystaline Berbasis Arduino di Kota Pangkalpinang
}

\author{
M. Yonggi Puriza ${ }^{1}$, Welly Yandi $^{2}$, Asmar $^{3}$ \\ Jurusan Teknik Elektro, Fakultas Teknik, Universitas Bangka Belitung ${ }^{1,2,3}$ \\ *myonggipuriza@ubb.ac.id
}

\begin{abstract}
This research contains complete evidences and experiments regarding decision making for the use of monocrystalline and polycrystalline solar panels, especially in the city of Pangkalpinang, Bangka Belitung Islands Province. Data collection between the two type solar panels compared was carried out for 30 days (23 September 2020 - 22 October 2020) through various weather conditions. The purpose of this research is to see and analyze the selection of suitable solar panels (monocrystalline or polycrystalline, $250 \mathrm{Wp}$ each with the same brand) for the city of Pangkalpinang in order to increase the energy supply more precisely and efficiently. The use of Arduino to retrieve data on solar panels is intended so that the data obtained will be more accurate and well mapped when compared to when the data is taken manually. The test results shows that monocrystalline solar panels are better than polycrystalline in energy generating by difference of $4.9 \%$.
\end{abstract}

Keywords : Efficiency, Energy, Monocrystalline, Polycrystalline, Pangkalpinang.

\section{INTISARI}

Dalam penelitian ini terkandung unsur pembuktian dan eksperimen yang lengkap mengenai pengambilan keputusan pemakaian panel surya tipe monocrystalline dan polycrystalline khususnya di kota Pangkalpinang, Provinsi Kepulauan Bangka Belitung. Pengambilan data antara kedua panel surya yang dibandingkan dilakukan selama 30 hari (23 September 2020 - 22 Oktober 2020) melalui berbagai macam cuaca. Tujuan dari penelitian ini adalah melihat dan menganalisa pemilihan tipe panel surya yang cocok (monocrystalline atau polycrystalline, masing - masing $250 \mathrm{Wp}$ dengan merek yang sama) untuk kota Pangkalpinang agar dapat meningkatkan suplai energi yang lebih tepat dan efisien. Penggunaan arduino untuk mengambil data pada panel surya dimaksudkan agar data yang didapatkan nantinya bisa lebih akurat dan terpetakan dengan baik jika dibandingan dengan apabila data diambil secara manual dengan cara dicatat. Hasil pengujian menyatakan bahwa panel surya jenis monocrystalline lebih baik dibandingkan polycrystalline dengan perbedaan energi yang dihasilkan sebesar $4.9 \%$.

Kata kunci: Efisiensi, Energi, Monocrystalline, Polycrystalline, Pangkalpinang.

\section{PENDAHULUAN}

Kota Pangkalpinang merupakan sebuah kota yang berada pada garis katulistiwa dengan iklim tropis. Akan tetapi kota Pangkalpinang berada di daerah kepulauan sehingga suhu udara lebih terasa panas dari pada daerah tropis lainnya. Oleh sebab itu, pariwisata di kota Pangkalpinang menjadi terkenal selain dari kondisi alam dan suhunya, situs-situs sejarah banyak juga kita temui di Pangkalpinang.

Perkembangan pariwisata menuntut pula berkembangnya hotel serta beberapa fasilitas kota lainnya. Sehingga kota Pangkalpinang memerlukan sumber daya yang besar baik itu sumber daya manusia ataupun sumber daya alamnya.

Salah satu sumber daya yang sangat dibutuhkan dikota Pangkalpinang adalah energi listrik. Untuk melakukan penambahan suplai energi listrik digunakanlah pembangkit energi terbarukan. Dengan digunakannya pembangkit energi terbarukan terutama solar panel, diharapkan agar pertumbuhan ekonomi Kota Pangkalpinang tidak terkendala dengan suplai energi listrik yang terbatas.

Penelitian ini pada prinsipnya membandingkan panel surya dua tipe monocrystalline dan polycrystalline khususnya di kota Pangkalpinang, 
Jurnal ECOTIPE, Vol. 8, No.1, April 2021, Hal. 47-52

p-ISSN 2355-5068, e-ISSN 2622-4852

Akreditasi Kemenristekdikti (SINTA 4), SK. No.10/E/KPT/2019

DOI: 10.33019/jurnalecotipe.v8i1.2034

Provinsi Kepulauan Bangka Belitung. Tujuan dari penelitian ini adalah melihat dan menganalisa pemilihan tipe panel surya yang cocok (monocrystalline atau polycrystalline) untuk kota Pangkalpinang agar dapat meningkatkan suplai energi yang lebih tepat dan efisien. Penggunaan arduino untuk mengambil data pada panel surya dimaksudkan agar data yang didapatkan nantinya bisa lebih akurat dan terpetakan dengan baik jika dibandingan dengan apabila data diambil secara manual dengan cara dicatat.

\section{LANDASAN TEORI}

PV (photovoltaic) atau sel surya adalah suatu alat yang dapat mengkonversi / mengubah energi matahari menjadi energi listrik. Jenis sel surya yang banyak beredar di pasaran adalah tipe Monocrystalline dan Polycrystalline. Sel Surya Silikon monocrystalline (c$\mathrm{Si}$ ) biasanya dibuat menggunakan proses Czochralski. Lapisan ini cenderung mahal karena mereka dipotong silinderingot (mirip bundar/lingkaran), ciri - ciri fisik solar cell ini adalah bentuknya yang segidelapan cenderung bulat dan warnanya yang agak gelap dan dapat mencapai efisiensi $17 \%$. Sel surya ini diklaim lebih baik daripada Polycrystalline [1] yang (P-Si) biasanya dibuat tidak menggunakan proses Czochralski seperti Monocrystalline tetapi dihasilkan melalui proses metalurgi grade silicone dengan pemurnian kimia sehingga tidak memiliki Ingot. [2].

Terkait dengan penelitian ini, terlebih dahulu Tsabitul Khair dkk (2018) telah melakukan penelitian dengan judul "Uji Komparatif Lapangan Jangka Pendek Produksi Energi Solar Photovoltaic Jenis Monocrystalline Dan Polycrystalline Pada Iklim Tropis". Penelitian ini membandingkan energi yang dihasilan oleh PV Monocrystalline Dan PV Polycrystalline $20 \mathrm{Wp}$ dengan memvariasikan sudut kemiringan PV tersebut sebesar $0^{0}, 15^{\circ}, 30^{\circ}, 45^{0}$ selama 7 hari di kota Pekanbaru Provinsi Riau dengan hasil yaitu PV monocrystalline lebih baik dibandingkan PV jenis polycrystalline dalam menghasilkan energi. [2].

Sedangkan Yulianta Siregar dkk (2015) melakukan penelitian dengan judul "Daya Output Optimal Pada Jenis Solar Cell Monocrystalline dan Polycrystalline" membandingkan daya yang dihasilkan oleh PV Monocrystalline dan PV Polycrystalline dengan menggunakan 2 jenis solar cell $100 \mathrm{Wp}$ yaitu Monocrystalline dan Polycrystalline dan di lakukan di gedung Departement Teknik Elekltro, Universitas Sumatera Utara, pada bulan Oktober 2015. Jenis Monocrystalline menggunakan sudut kemiringan solar cell $0^{\circ}-60^{\circ}$, sementara jenis Polycrystalline menggunakan reflektor (Cermin) dengan sudut reflektor $50^{\circ}, 60^{\circ}$ dan $70^{\circ}$. Hasil daya output optimal yang di peroleh untuk Monocrystalline adalah sebesar 100 Watt, pada Jam 12.00 WIB dengan sudut kemiringan solar cell $10^{\circ}$ dan berada pada posisi sudut azimuth matahari, sedangkan unfuk Polycrystalline daya output optimal sebesar 100 Watt , pada jam 12.00 WIB dengan sudut kemiringan reflektor $60^{\circ}$ dan sudut kemiringan solar cell $10^{\circ}$. [3]

Penelitian lainnya oleh Denny Suryana dkk (2016) yang meneliti tentang kaitan antara suhu/temperatur pada sel surya dengan tegangan yang diproduksi oleh sel surya tersebut dan menyimpulkan bahwa Akibat kenaikan temperatur, maka Tegangan listrik yang diproduksi oleh panel surya menjadi berkurang. Untuk kondisi Surabaya, terjadi pengurangan tegangan listrik sebesar $0.22 \mathrm{~V} /{ }^{\circ} \mathrm{C}$ jika menggunakan panel surya jenis monocrystalline. [4]

Penelitian selanjutnya oleh M. Barkah Salim dkk (2019) melakukan analisis jenis panel surya monocrystalline 150 watt. Tujuan dari penelitian ini adalah untuk menganalisis besar arus dan tegangan yang dihasilkan panel surya pada beberapa keadaan langit yaitu mendung, cerah berawan, cerah. Metode penelitian yang dilakukan adalah eksperimen. Dari data yang sudah didapatkan bahwa energi yang dihasilkan oleh panel surya pada saat mendung berkisar 0,6-0,8 ampere, saat cerah berawan 0,9-1,9 ampere, dan saat cerah 2,0-3,2 ampere. Besar energi listrik yang mampu dihasilkan sebesar 8\%. Akan tetapi apabila keadaan cerah bisa menghasilkan dua kali lipatnya. [5]

Sedangkan penelitian lain yang terkait energi listrik matahari yang dihasilkan oleh panel surya di pulau Bangka Belitung terbatas sekali, tercatat hanya 3 artikel yaitu Solar Energy Potential in Bangka Belitung Islands, Indonesia, Utilization Photovoltaic for Electrical Energy Needs in Kelapan Island, Indonesia dan Suitability Analysis for Solar Photovoltaic Development in East Belitung Regency. [6][7][8]

Seiring dengan berkembangnya dan makin diminatinya pemakaian solar cell di kota Pangkalpinang, maka dibutuhkan studi komparasi kedua jenis panel surya untuk menentukan mana yang 
Jurnal ECOTIPE, Vol. 8, No.1, April 2021, Hal. 47-52

p-ISSN 2355-5068, e-ISSN 2622-4852

Akreditasi Kemenristekdikti (SINTA 4), SK. No.10/E/KPT/2019

DOI: 10.33019/jurnalecotipe.v8i1.2034

lebih baik dipakai baik dari segi suhu, energi, tegangan, arus dan daya yang dihasilkan dan meningkatkan nilai efisiensi listrik yang terbangkitkan sehingga dalam penelitan ini akan terkandung unsur pembuktian dan eksperimen yang lengkap mengenai pengambilan keputusan pemakaian panel surya tipe monocrystalline dan polycrystalline khususnya di kota Pangkalpinang ini.

\section{METODE PENELITIAN}

Panel surya tipe polycrystalline dan monocrystalline dilakukan pengecekan kapasitas $\mathrm{Wp}$ yang dimiliki agar ketika dilakukan pengambilan data perbandingan mendapatkan data yang akurat. Pemasangan kedua panel surya dilakukan di lokasi yang sama agar sinar matahari yang diterima oleh kedua panel surya juga sama. Pengecekan keluaran konversi energi listrik dari panel surya dilakukan secara manual agar ketika pengambilan data didapatkan data yang akurat sesuai kapasitas panel surya.

Hasil pengukuran yang akan dijadikan data penelitian dimonitor dengan sebuah alat yang terdiri dari beberapa komponen yang dihubungkan dan diprogram sehingga dapat bekerja sesuai dengan yang diharapkan. Komponen utama yang digunakan pada alat tersebut adalah arduino jenis UNO R3. Selan itu ada beberapa sensor yang digunakan diantaranya adalah sensor tegangan dan arus. Sensor-sensor yang digunakan akan melakukan monitoring data keluaran panel surya dan mengirimkan data tersebut menuju arduino untuk diproses menjadi sebuah data yang lebih terstruktur dan mudah dipahami yaitu dalam bentuk data microsoft excel. Data yang telah diperoleh dalam bentuk excel akan dibandingkan sehingga didapatkan kurva perbandingan agar mudah menarik kesimpulan tipe panel surya yang manakah yang sesuai digunakan di kota Pangkalpinang.

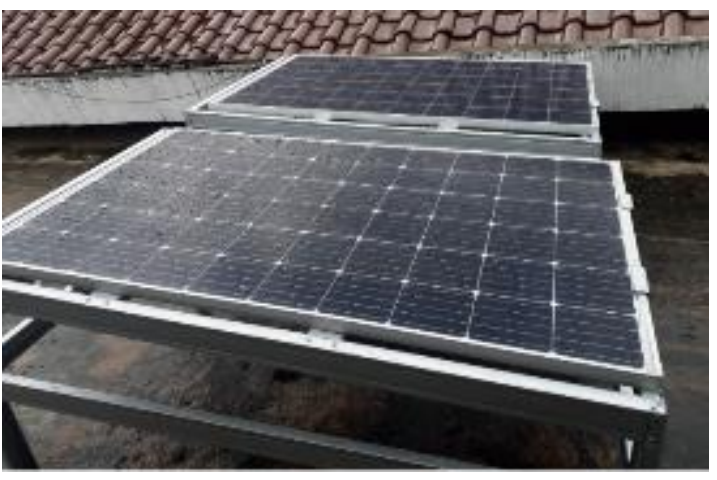

Gambar 1. Panel surya $250 \mathrm{Wp}$ yang digunakan dengan merk dan pabrikasi yang sama

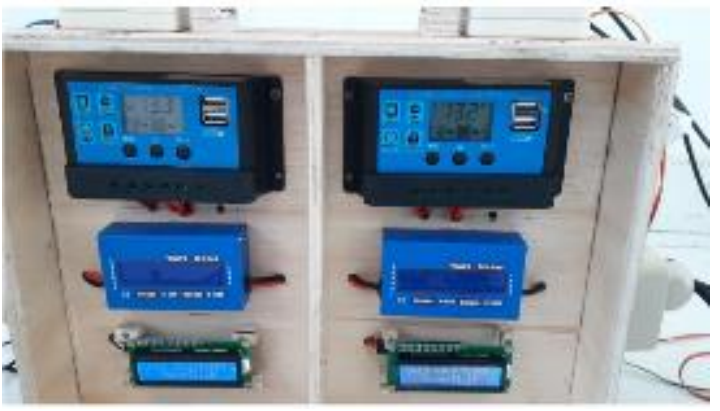

Gambar 2. Arduino, sensor, alat ukur dan kontroler yang digunakan

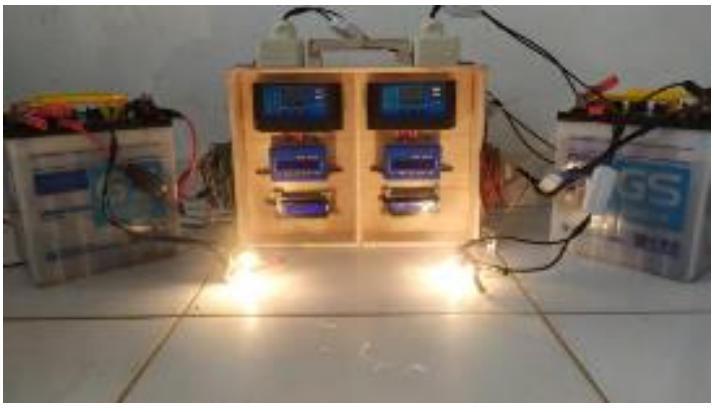

Gambar 3. Baterai, beban dan kontroler

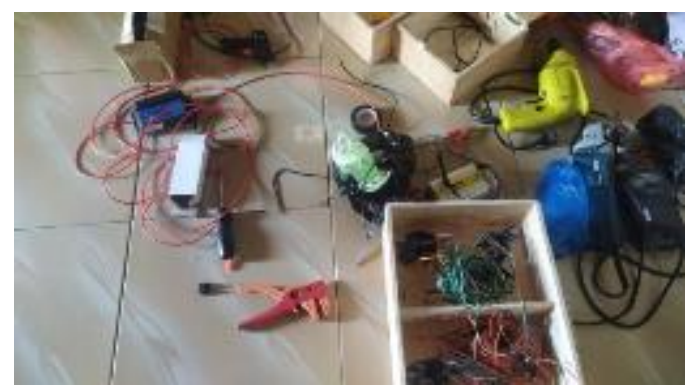

Gambar 4. Proses perakitan alat 
Jurnal ECOTIPE, Vol. 8, No.1, April 2021, Hal. 47-52

p-ISSN 2355-5068, e-ISSN 2622-4852

Akreditasi Kemenristekdikti (SINTA 4), SK. No.10/E/KPT/2019

DOI: 10.33019/jurnalecotipe.v8i1.2034

Data yang diambil adalah data berupa tegangan dan arus berdasarkan waktu. Untuk mendapatkan daya dari data yang diperoleh maka digunakanlah rumus perhitungan daya sederhana yang bisa diperoleh dari perkalian tegangan dan arus.

$$
P=V \times I
$$

Sementara energi diperoleh dari perkalian tegangan dan arus berdasarkan waktu dan energi total dihitung dalam waktu 1 jam atau 1 hari.

$$
W=V x I x t
$$

atau

$$
\begin{aligned}
& W=P x t \\
& W_{\text {Total }}=\sum W
\end{aligned}
$$

dimana :

$$
\begin{array}{ll}
\mathrm{P} & =\text { Daya } \\
\mathrm{V} & =\text { Tegangan } \\
\mathrm{I} & =\text { Arus } \\
\mathrm{W} & =\text { Energi } \\
\mathrm{W}_{\text {total }} & =\text { Total Energi }
\end{array}
$$

Data tersebut akan menunjukkan secara rinci panel surya yang memiliki kemampuan cocok untuk digunakan dan diaplikasikan sebagai alternatif pembangkit energi terbarukan khususnya di kota Pangkalpinang

\section{HASIL PENELITIAN DAN PEMBAHASAN}

Hasil data diambil selama 30 hari sejak tanggal 23 September 2020 sampai dengan tanggal 22 Oktober 2020 selama 12 jam setiap harinya mulai dari pukul 06.00 WIB sampai pukul 18.00 WIB dengan cuaca dan intensitas matahari yang bervariasi. Arduino akan mencatat data dan diatur merekam data secara kontinyu setiap 1 menit sekali sehingga setiap hari akan menghasilkan sebanyak 1442 data untuk masingmasing arus dan tegangannya dari kedua jenis panel surya $250 \mathrm{Wp}$ ini.

Dari data mentah tersebut diperoleh data tegangan, arus, daya dan energi rata-rata serta total energi selama 12 jam perhari selama 30 hari pengambilan data dari masing-masing jenis panel surya untuk dibandingkan.
Tabel 1. Nilai Rata - Rata Pengukuran Panel Surya Monocrystalline

\begin{tabular}{|c|c|c|c|c|}
\hline Jam & Tegangan (volt) & Arus (ampere) & Daya (watt) & Energi (Wh) \\
\hline $6: 00$ & 12,06 & 0,34 & 4,12 & 0,00 \\
\hline $7: 00$ & 12,39 & 0,85 & 10,65 & 6,81 \\
\hline $8: 00$ & 12,82 & 2,37 & 31,15 & 21,00 \\
\hline $9: 00$ & 13,02 & 3,68 & 49,26 & 40,73 \\
\hline $10: 00$ & 13,16 & 4,17 & 55,74 & 52,71 \\
\hline $11: 00$ & 13,25 & 5,47 & 74,30 & 62,38 \\
\hline $12: 00$ & 12,66 & 4,50 & 59,34 & 68,12 \\
\hline $13: 00$ & 12,57 & 4,48 & 58,73 & 59,92 \\
\hline $14: 00$ & 12,88 & 3,36 & 44,03 & 53,56 \\
\hline $15: 00$ & 12,70 & 2,47 & 31,70 & 36,89 \\
\hline $16: 00$ & 12,49 & 1,29 & 16,13 & 23,21 \\
\hline $17: 00$ & 12,30 & 0,27 & 3,30 & 8,38 \\
\hline $18: 00$ & 12,12 & 0,03 & 0,36 & 1,23 \\
\hline
\end{tabular}

Tabel 2. Nilai Rata - Rata Pengukuran Panel Surya Polycrystalline

\begin{tabular}{|c|c|c|c|c|}
\hline Jam & Tegangan (volt) & Arus (ampere) & Daya (watt) & Energi (Wh) \\
\hline $6: 00$ & 12,23 & 0,30 & 3,73 & 0,00 \\
\hline $7: 00$ & 12,46 & 1,26 & 15,84 & 9,29 \\
\hline $8: 00$ & 12,77 & 2,03 & 26,53 & 21,69 \\
\hline $9: 00$ & 12,95 & 3,50 & 46,62 & 37,40 \\
\hline $10: 00$ & 13,03 & 4,00 & 53,18 & 49,16 \\
\hline $11: 00$ & 13,15 & 5,39 & 72,73 & 59,65 \\
\hline $12: 00$ & 12,53 & 4,02 & 52,59 & 65,76 \\
\hline $13: 00$ & 12,38 & 4,25 & 54,79 & 57,07 \\
\hline $14: 00$ & 12,71 & 3,18 & 41,17 & 50,23 \\
\hline $15: 00$ & 12,61 & 2,10 & 26,97 & 33,32 \\
\hline $16: 00$ & 12,39 & 1,21 & 15,11 & 21,12 \\
\hline $17: 00$ & 12,25 & 0,29 & 3,51 & 7,62 \\
\hline $18: 00$ & 12,09 & 0,01 & 0,17 & 1,32 \\
\hline
\end{tabular}

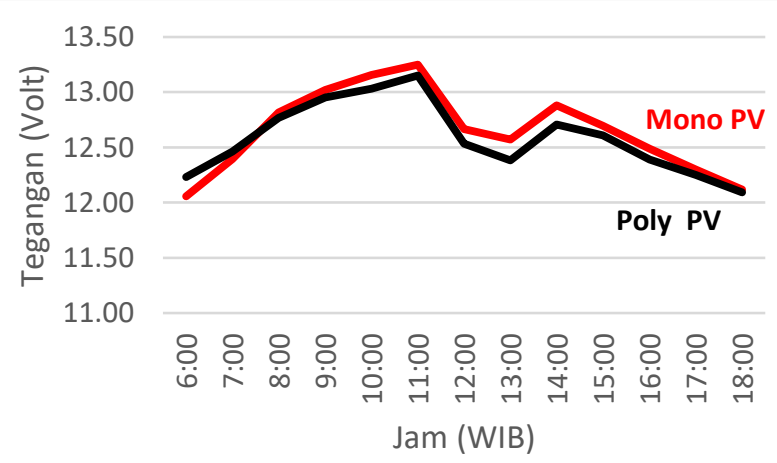

Gambar 5. Kurva rata-rata 30 hari perbandingan tegangan panel surya selama 12 jam pengukuran

Dari Gambar 5 terlihat bahwa tegangan terendah dari kedua panel surya terjadi pada pukul 06.00 dan 
Jurnal ECOTIPE, Vol. 8, No.1, April 2021, Hal. 47-52

p-ISSN 2355-5068, e-ISSN 2622-4852

Akreditasi Kemenristekdikti (SINTA 4), SK. No.10/E/KPT/2019

DOI: 10.33019/jurnalecotipe.v8i1.2034

18.00 dimana intensitas sinar matahari sudah jauh berkurang dan tegangan tertinggi dicapai sekitar pukul 11.00 sampai pukul 12.00 dimana intensitas sinar matahari sangat tinggi pada jam tersebut.

Dapat disimpulkan juga dari gambar 5 bahwa tegangan terbaik rata-rata dicapai oleh panel surya monocrystalline dibandingkan panel surya jenis polycrystalline.

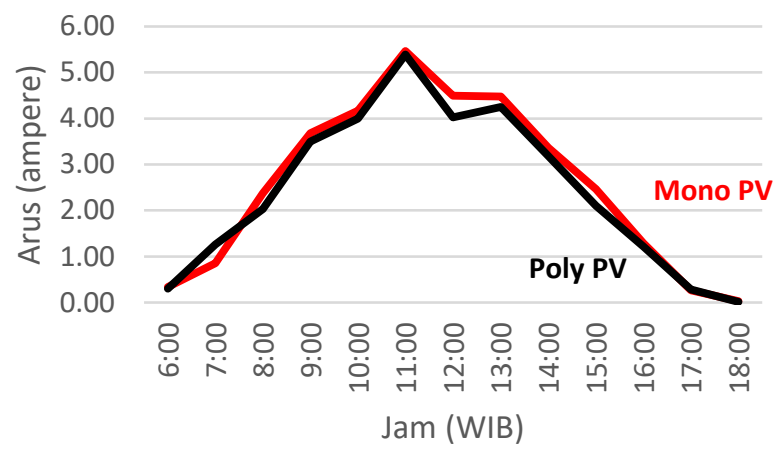

Gambar 6. Kurva rata-rata 30 hari perbandingan arus panel surya selama 12 jam pengukuran

Dari Gambar 6 terlihat bahwa bentuk kurva seperti parabola yang menghadap ke bawah dimana arus tertinggi rata-rata kedua panel dicapai sekitar pukul 11.00 dan arus terendah rata-rata kedua panel didapat sekitar pukul 06.00 pagi dan pukul 18.00 sore hari, hal ini juga tentu terjadi karena intensitas sinar matahari yang maksimal pada siang hari dan minimal pada pagi dan sore hari.

Panel surya monocrystalline juga lebih baik jika dilihat dari jenis data ini dibandingkan panel surya polycrystalline.

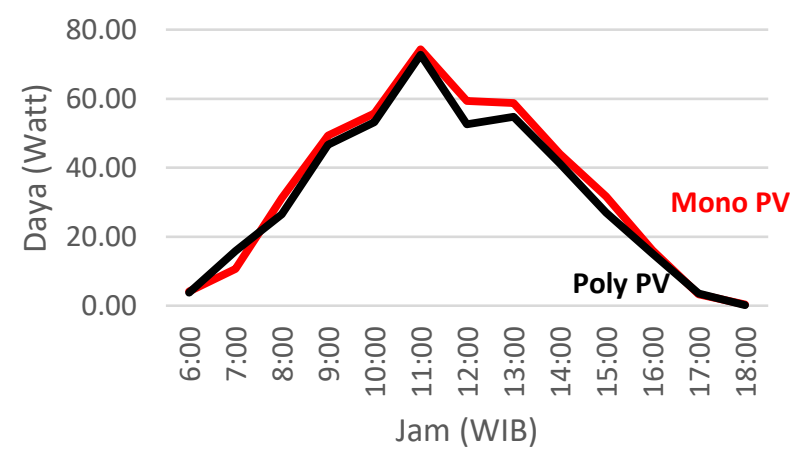

Gambar 7. Kurva rata-rata 30 hari perbandingan daya panel surya selama 12 jam pengukuran
Daya rata-rata per jam juga lebih baik panel surya jenis monocrystalline walaupun tidak signifikan karena data daya didapatkan dari perkalian arus dan tegangan seperti yang ditunjukkan pada Gambar 7 .

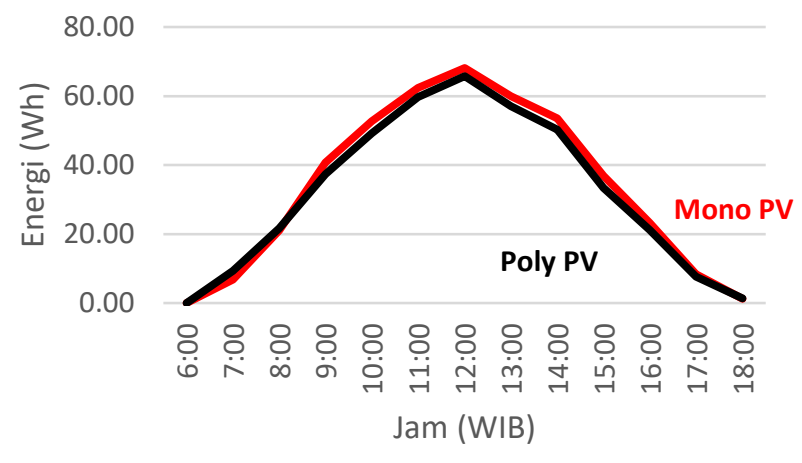

Gambar 8. Kurva rata-rata 30 hari perbandingan energi panel surya selama 12 jam pengukuran

Kurva energi rata-rata yang dihasilkan oleh kedua jenis panel surya dapat dilihat pada gambar 8 diatas, dimana panel surya jenis monocrystalline menghasilkan energi $4.9 \%$ lebih tinggi dibandingkan panel surya jenis polycrystalline. Nilai tersebut tidak besar tetapi membuktikan bahwa panel surya jenis monocrystalline tetap lebih baik dibandingkan polycrystalline.

Tabel 3. Total Energi yang Dihasilkan oleh Kedua Panel Surya Selama 30 Hari

\begin{tabular}{|c|c|c|c|c|c|}
\hline Hari ke & $\begin{array}{c}\text { Total Energi } \\
\text { monocrystalline } \\
\text { PV }\end{array}$ & $\begin{array}{c}\text { Total Energi } \\
\text { polycrystalline } \\
\text { PV }\end{array}$ & Hari ke & $\begin{array}{c}\text { Total Energi } \\
\text { monocrystalline } \\
\text { PV }\end{array}$ & $\begin{array}{c}\text { Total Energi } \\
\text { polycrystalline } \\
\text { PV }\end{array}$ \\
\hline 1 & 496,12 & 481,27 & 16 & 145,04 & 128,38 \\
\hline 2 & 664,53 & 644,57 & 17 & 429,55 & 401,39 \\
\hline 3 & 205,87 & 187,63 & 18 & 247,83 & 238,45 \\
\hline 4 & 306,12 & 275,49 & 19 & 197,23 & 188,86 \\
\hline 5 & 290,30 & 271,43 & 20 & 263,50 & 255,78 \\
\hline 6 & 722,95 & 682,81 & 21 & 342,67 & 321,33 \\
\hline 7 & 785,32 & 764,91 & 22 & 179,11 & 176,14 \\
\hline 8 & 237,31 & 235,96 & 23 & 440,00 & 436,46 \\
\hline 9 & 597,88 & 575,22 & 24 & 443,19 & 439,04 \\
\hline 10 & 503,75 & 480,11 & 25 & 375,56 & 368,39 \\
\hline 11 & 376,09 & 351,64 & 26 & 404,29 & 382,64 \\
\hline 12 & 631,07 & 591,01 & 27 & 466,46 & 443,98 \\
\hline 13 & 713,63 & 660,36 & 28 & 627,23 & 571,39 \\
\hline 14 & 429,36 & 404,73 & 29 & 590,08 & 547,93 \\
\hline 15 & 511,90 & 502,10 & 30 & 424,27 & 399,20 \\
\hline & & & & & \\
\hline
\end{tabular}


Jurnal ECOTIPE, Vol. 8, No.1, April 2021, Hal. 47-52

p-ISSN 2355-5068, e-ISSN 2622-4852

Akreditasi Kemenristekdikti (SINTA 4), SK. No.10/E/KPT/2019

DOI: 10.33019/jurnalecotipe.v8i1.2034

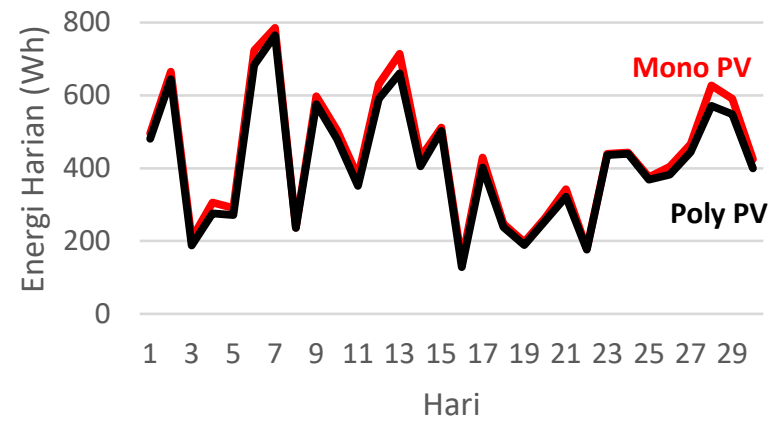

Tabel 9. Kurva perbandingan total energi yang dihasilkan oleh kedua panel surya selama 30 hari

Dari kurva Gambar 9 terlihat bahwa energi harian yang dihasilkan fluktuatif, hal ini terjadi karena cuaca pengambilan data 30 hari terhitung sejak tanggal 23 September 2020 sampai dengan tanggal 22 Oktober 2020 berbeda - beda, terkadang hujan dan terkadang cerah dan tentu saja mempengaruhi intensitas cahaya matahari yang diterima oleh masing-masing panel surya.

\section{KESIMPULAN}

Pengambilan data selama 30 hari sejak tanggal 23 September 2020 sampai dengan tanggal 22 oktober 2020 selama 12 jam yang dimulai dari pukul $06.00 \mathrm{wib}$ sampai pukul 18.00 wib dengan cuaca yang berbedabeda di Kota Pangkalpinan Provinsi Kepualauan Bangka Belitung menghasilkan kesimpulan bahwa panel surya jenis monocrystalline menghasilkan energi 4.9\% lebih tinggi dibandingkan panel surya jenis polycrystalline dengan daya peak panel surya yang sama $(250 \mathrm{Wp})$ dan merek yang sama pula (Solana).

\section{UCAPAN TERIMAKASIH}

Penulis mengucapkan terimakasih kepada KEMENRISTEK/BRIN yang telah mendanai penelitian ini melalui skema PDP/Dosen Pemula.

Penulis juga mengucapkan terimakasih kepada Jurusan Teknik Elektro, Fakultas Teknik dan Universitas Bangka Belitung yang telah membantu dalam publikasi artikel penelitian ini.

\section{REFERENSI}

[1] Swami, R. 2012. Solar Cell. International Journal of Scientific and Research Publications. 2(7): 1-5.

[2] T. Khair, R. Iswandi, Hasyim. 2018. Uji Komparatif Lapangan Jangka Pendek Produksi Energi Solar Photovoltaic Jenis Monocrystalline dan Polycrystalline Pada Iklim Tropis. Jom FTEKNIK. 5(Januari s/d Juni): 1-5.

[3] Y. Siregar, dkk. 2015. Daya Output Optimal Pada Jenis Solar Cell Monocrystalline dan Polycrystalline. Jurnal Teknika Untirta. 11(2): 6579.

[4] D. Suryana, M., M. Ali. 2016. Pengaruh Temperatur / Suhu Terhadap Tegangan Yang Dihasilkan Panel Surya Jenis Monokristalin (Studi kasus: Baristand Industri Surabaya). Jurnal Teknologi Proses dan Inovasi Industri. 2(1): 49-52

[5] M. B. Salim, N. Rajabiah. 2019. Analisis Kemampuan Panel Surya Monokristalin 150 Watt Pada Arus dan Pengisian Yang Dihasilkan. JIPFRI. 3(1): 29-35

[6] Y. Tiandho, I. Dinata, W. Sunanda , R. F. Gusa and D. Novitasari 2019 Solar energy potential in Bangka Belitung islands, Indonesia (IOP Conf. Ser.: Earth Environ. Sci. vol 257 ) pp 1-7

[7] I. Pansuri, W. Sunanda and R. F. Gusa 2019 Utilization Photovoltaic for Electrical Energy Needs in Kelapan Island, Indonesia (IOP Conf. Ser: Materials Science and Engineering, Vol 830) pp 1-4

[8] S. Z. Muwafiq. 2019. Suitability Analysis for Solar Photovoltaic Development in East Belitung Regency (IOP Conf Ser: Earth and Environmental Science, Vol 248) 